\title{
ANALISIS SIKAP KONSUMEN TERHADAP KEPUTUSAN PEMBELIAN PRODUK SEPEDA MOTOR HONDA MEREK VARIO PADA PD. DAYA MOTOR SUNGAI BAHAR MUARO JAMBI
}

\author{
Ahmad Tarmizi ${ }^{1}$
}

\begin{abstract}
The purpose of the research is to find out and analyze the attitude of consumers towards products of honda motor vehicles branded vario on PD. Motor Power Muaro Jambi. The number of samples that will be taken is as much as 100 people respondents. Sample withdrawal technique is done in a non probability of simple random sampling. Analysis tools are used multiple linear regression. Research results from theTest $F F$ values obtained to calculate probability with 41.855 of 0.000 . Because F count $42.193>F 2.47$ and the probability Table is much smaller than 0.05 regression models then can be used to predict future purchasing decisions (the dependent variable) or it can be said that all independent variables namely Utilitarian Function, the expression value, maintain the ego and knowledge together effect on the dependentvariable consumer purchasing decisions against the Honda brand Vario. The coefficient of determination (R2) above shows the magnitude of the adjusted $R 2$ is 0.640, this means that $64 \%$ of the variations in purchase decisions can be explained by the variation of 4 independent variables. The $t$ test analysis results above is a value $t$ calculate on variable Utilitarian (X 1). variable expression of the value (X 2) Defending the Ego (X 3), variable knowledge (X 4) significance level of 0.000 significance probability $\alpha=<0.05$, then Ho denied and Ha is received. This means the variables $x 1, \times 2, x 3, X 4$ positive and significant effect against the decision
\end{abstract}

Key word: attitude, consumer, purchase

\section{PENDAHULUAN}

Salah satu faktor yang memenuhi keberhasilan suatu perusahaan untuk mempertahankan konsumennya tergantung pada berhasil tidaknya kegiatan pemasaran yang dilakukan. Kegiatan pemasaran merupakan salah satu fungsi dari kegiatan yang dilakukan oleh perusahaan. Kegiatan pemasaran berperan penting dalam menentukan maju mundurnya suatu perusahaan. Pemasaran diharapkan mampu menyalurkan produk-produk yang ditawarkan produsen agar dibeli oleh konsumen, karena perusahaan tidak mampu menjual produknya ke pasar tanpa dukungan oleh fungsi pemasaran yang baik atau handal meskipun pelaksanaan fungsi bisnis lainnya telah berjalan secara efisien. Oleh karena itu fungsi pemasaran sering dikatakan sebagai ujung tombak kegiatan suatu perusahaan.

Sedangkan pemasaran menurut kotler (2002:9) adalah suatu proses sosial dan manajerial yang didalamnya individu dan kelompok mendapatkan apa yang mereka butuhkan dan inginkan dengan menciptakan, menawarkan dan mempertukarkan produk yang bernilai dengan pihak lain.

Dalam manajemen pemasaran ditekankan bahwa para pemasar wajib memahami keragaman dan kesamaan konsumen agar mereka mampu memasarkan produknya dengan baik. Para pemasar harus memahami mengapa dan bagaimana konsumen mengambil keputusan konsumsi sehingga para pemasar dapat merancang strategi pemasaran dengan lebih baik. Pemasar yang mengerti tentang sikap konsumen akan mampu memperkirakan bagaimana kecenderungan konsumen untuk memperkirakan bagaimana kecenderungan konsumen untuk

${ }^{1}$ Dosen Fakultas Ekonomi Universitas Batanghari 
bereaksi terhadap informasi yang diterimanya, sehingga pemasar dapat menyusun strategi pemasaran yang sesuai.

Sikap menurut Kotler (2002 :200 ), sikap adalah evaluasi, perasaan emosional dan kecenderungan tindakan atau tidak menguntungkan dan bertahan lama dari seseorang terhadap suatu objek atau gagasan. Sikap memegang peranan yang penting dalam membentuk suatu perilaku. Sikap konsumen adalah faktor penting yang akan mempengaruhi keputusan konsumen. Pada umumnya, sikap digunakan untuk menilai efektifitas kegiatan pemasaran.Sikap menempatkan seseorang ke dalam suatu pikiran untuk menyukai dan tidak menyukai sesuatu, bergerak mendekati atau menjauhi sesuatu,bergerak mendekati atau menjauhi sesuatu tersebut. Ada kecenderungan untuk menganggap bahwa sikap merupakan faktor yang tepat untuk meramalkan perilaku yang akan datang. Jadi, dengan mempelajari sikap, seseorang diharapkan dapat menentukan apa yang akan dilakukannya.

Meningkatnya kesejahteraan masyarakat serta pengetahuan yang semakin luas membuat masyarakat semakin pintar dan selektif dalam memilih produk untuk memenuhi kebutuhannya, ditambah lagi semakin banyaknya informasiinformasi yang diperoleh sehingga banyak pilihan bagi konsumen untuk memilih produk. Bagi perusahaan-perusahaan ini merupakan suatu tugas penting yang harus dihadapi.

Produk menurut Tjiptono (2008 ; hal 95 ), produk adalah segala sesuatu yang ditawarkan produsen untuk diperhatikan, diminati, dicari, digunakan atau dikonsumsi pasar sebagai pemenuhan kebutuhan atau keinginan pasar yang bersangkutan. Kualitas adalah suatu kondisi dinamis yang berhubungan dengan produk, jasa, manusia, proses dan lingkungan yang memenuhi atau melebihi harapan konsumen.

Salah satu kebutuhan manusia yang sangat berarti adalah kebutuhan akan transportasi untuk berjalan dari tempat yang satu ke tempat yang lain dengan cepat tanpa ada hambatan untuk menuju tempat yang diinginkan. Pada zaman sekarang transportasi berupa sepeda motor diperlukan bahkan menjadi bagian kebutuhan yang tidak dapat dipisahkan. Produk sepeda motor sudah beraneka ragam jenis khususnya produk motor Honda yang merupakan buatan Jepang dan telah dirakit di Indonesia dengan lisensinya.

Honda berada di Indonesia sejak tahun 1974 dan tidak asing lagi bagi masyarakat. Produk sepeda motor yang dihasilkan Honda terdiri atas 3 jenis yaitu:

Nama produk sepeda motor

Pada PD.DAYA MOTOR Sungai Bahar

\begin{tabular}{crll}
\hline No & Jenis Produk & & Nama Produk \\
\hline 1. & Sepeda motor bebek & Supra X \\
& & Revo \\
2. & Sepeda motor matic & Vario \\
& & Beat \\
& & Scoopy \\
3. & sepeda motor besar & Mega Pro \\
& & CBR \\
& & Tiger \\
\hline
\end{tabular}


Data Volume Penjualan Sepeda Motor Honda VarioTahun 2012-2016

\begin{tabular}{ccc}
\hline Tahun & $\begin{array}{c}\text { Volume Penjualan } \\
\text { (Unit) }\end{array}$ & $\begin{array}{c}\text { Perkembangan } \\
(\boldsymbol{\%})\end{array}$ \\
\hline $\mathbf{2 0 1 2}$ & 1.279 & - \\
$\mathbf{2 0 1 3}$ & 1.450 & 0,12 \\
$\mathbf{2 0 1 4}$ & 1.324 & $-0,10$ \\
$\mathbf{2 0 1 5}$ & 1.516 & 0,13 \\
$\mathbf{2 0 1 6}$ & 1.275 & $-0,19$ \\
\hline
\end{tabular}

Sumber: laporan penjualan PD. Daya Motor Sungai Bahar Muaro Jambi tahun $2012-2016$

Dari tabel 1.2 diatas, dapat di jelaskan bahwa jumlah penjualan pada periode 2015 sebanyak 1.516 unit, dalam hal ini periode 2015 memiliki jumlah penjualan terbanyak bila dibandingkan periode sebelumnya, sedangkan periode 2016 hanya memiliki jumlah penjualan sebanyak 1.275 unit yang menandakan bahwa penjualan sepeda motor Honda Vario dari tahun 2012-2016 mengalami fluktuasi dan cenderung mengalami penurunan.

Adapun banyaknya jumlah konsumen (orang) selama periode 2012-2016 dapat dilihat pada tabel dibawah ini:

Data Jumlah Konsumen Tahun 2012-2016

\begin{tabular}{ccc}
\hline Tahun & $\begin{array}{c}\text { Jumlah Konsumen } \\
\text { (Orang) }\end{array}$ & $\begin{array}{c}\text { Perkembangan } \\
(\mathbf{\%})\end{array}$ \\
\hline 2012 & 927 & - \\
2013 & 1050 & 0 \\
2014 & 1125 & 0,07 \\
2015 & 1280 & 0,12 \\
2016 & 1183 & $-0,08$ \\
\hline
\end{tabular}

Sumber: Data jumlah konsumen PD. Daya Motor Sungai Bahar Muaro Jambi tahun $2012-2016$

Perusahaan-perusahaan yang ada kini semakin meningkatkan kualitas produk jasa yang dihasilkan, ini semua bertujuan untuk memenuhi kepuasan konsumennya maka perusahaan terus mampu menarik minat konsumen salah satunya melalui produk, suatu produk yang berkualitas merupakan aset perusahaan yang paling bernilai dan dapat memberikan gambaran tentang prospek di tahun mendatang.

Sedangkan merek memegang peranan penting dalam upaya menarik minat konsumen dan mempertahankan konsumen yang sudah ada. Menurut Durianto dan kawan-kawan (2001) merek merupakan nama, istilah, tanda, simbol, desain atau kombinasinya yang memberikan ciri dari suatu produk atau jasa yang dihasilkan oleh perusahaan sehingga konsumen mudah untuk mengetahui produk tersebut.

Identifikasi tersebut juga berfungsi untuk membedakan dengan produk yang ditawarkan oleh perusahaan pesaing. Merek juga merupakan nilai tangible dan intangible yang terwakili oleh trade mark (merek dagang) yang mampu menciptakan nilai dan pengaruh tersendiri dinpasar bila diatur dengan tepat. Betapa pentingnya suatu merek terhadap suatu produk yang akan ditawarkan pada konsumennya.Kualitas produk yang baik juga berpengaruh penting dalam membentuk perilaku konsumen. Tingkat kepuasan dan perilaku konsumen 
menjadi ukuran mengenai keberhasilan strategi pemasaran yang diterapkan perusahaan-perusahaan. Kepuasan menurut Kotler dalam Lopiyuadi (2001: hal 58), kepuasan adalah tingkat perasaan dimana seseorang menyatakan hasil perbandingan atas kinerja produk/jasa yang diterima atau diharapkan.

Sikap menurut Allportndikutip oleh loundon dan Della Bitta ( dalam Nugroho J. Setiadi) sikap adalah suatu mental dan saraf sehubungan dengan kesiapan untuk menanggapi, diorganisasi melalui pengalaman dan memiliki pengaruh yang mengarah dan atau dinamis terhadap perilaku. Sikap juga memainkan peranan utama dalam membentuk perilaku dengan melakukan riset pasar tentang sikap, baik sikap sebelum atau sudah membeli dan tanggapan konsumen terhadap produk tersebut.

Daniel Kazt (Setiadi 2013 hal 145) mengklasifikasikan empat sikap yaitu :

\section{Fungsi Utillitarian}

Merupakan fungsi yang berhubungan dengan prinsip-prinsip dasar imbalan dan hukuman. Berdasarkan apakah produk tersebut memberikan kepuasan atau kekecewaan.

2. Fungsi Ekspresi Nilai

Konsumen mengembangkan sikap terhadap suatu merek produk bukan didasarkan atas manfaat produk itu, tapi didasarkan atas kemampuan merek produk itu mengekspresikan nilai-nilai yang ada pada dirinya.

3. Fungsi Mempertahankan Ego

Sikap yang dikembangkan oleh konsumen cenderung untuk melindunginya dari tantangan ekternal maupun perasaan internal, sehingga membentuk fungsi mempertahankan ego.

4. Fungsi Pengetahuan

Sikap membantu konsumen mengorganisasikan informasi yang begitu banyak yang setiap hari dipaparkan pada dirinya. Fungsi ini dapat membantu konsumen mengurangi ketidakpastian dan kebingungan dalam memilah informasi yang relevan dan yang tidak relevan.

Sikap konsumen mempunyai peranan penting di dalam membentuk perilaku konsumen. Dengan mengetahui sikap konsumen, maka perusahan akan dapat mengetahui kebutuhan dan perilaku konsumen. Sehingga perusahaan dapat meningkatkan kualitas dari barang jasa yang dihasilkan dengan demikian tercapailah tujuan perusahaan yaitu kepuasan konsumen. Sifat yang penting dari sikap adalah keyakinan(kepercayaan) dalam memegang sikaptersebut. Sikap yang dipegang dengan keyakinan yang kuat akan jauh lebih diandalkan dalam melihat perilaku konsumen.

Konsumen menurut Swastha (2000 : hal 12 ), konsumen adalah individuindividu yang melakukan pembelian untuk memenuhi kebutuhan pribadinya atau konsumen rumah tangga. Dalam melakukan pembelian atas suatu produk, dipengaruhi oleh banyak faktor rangsangan dari luar, yaitu rangsangan pemasaran dari penjual dan kekuatan rangsangan ekonomi,teknologi,politik dan budaya serta karakteristik dan proses keputusan pembelian( Kotler :65: 2002 ). Sikap konsumen merupakan sifat interval individual, yaitu sifat dari dalam individu yang mempengaruhi proses pengambilan keputusan, antar lain belajar, kepribadian, konsep diri, sikap dan kepercayaan, sedangkan perilaku lebih bersifat eksternal individu, kelas sosial, kelompok referensi dan keluarga (Swastha \& T.H Handoko, 2002 ). 
Pada umumnya konsumen menginginkan kendaraan sepeda motor yang memiliki keunggulan mesin, ketahanan, kecepatan, ketepatan dan body yang bagus dan itulah yang dimiliki oleh produk Honda.

Rumusan masalah dalam penelitian ini adalah : 1) Bagaimana sikap konsumen dan kepuasan pembelian produk Sepeda Motor Honda Merek Variopada PD. Daya Motor Sungai Bahar Muaro Jambi. 2) Bagaimana pengaruh sikap konsumen terhadap kepuasan pembelian produk Sepeda Motor Honda Merek Variopada PD. Daya Motor Sungai Bahar Muaro Jambi.

Tujuan dari penelitian ini adalah : 1) Untuk mengetahui sikap konsumen dan kepuasan pembelian produk Sepeda Motor Honda Merek vario pada PD.Daya Motor Sungai Bahar Muaro Jambi. 2) Untuk mengetahui pengaruh sikap konsumen terhadap kepuasan pembelian produk Sepeda Motor Honda Merek vario pada PD.Daya Motor Sungai Bahar Muaro Jambi

Dalam penelitian ini, peneliti menggunakan metode survey, yaitu data-data dikumpulkan oleh peneliti berdasarkan jawaban responden atas pertanyaanpertanyaan yang diajukan peneliti melalui wawancara pribadi dengan menggunakan kuesioner. Metode ini digunakan karena metode ini dianggap cukup ekonomis, cepat, serta menjamin keluasan responden untuk menjawab pertanyaan. Adapun yang menjadi objek peneliti ini adalah Konsumen Honda vario di kecamatan Sungai Bahar. Dalam penelitian ini data yang digunakan adalah konsumen yang memakai produk sepeda motor merek Honda vario yang berada di Kecamatan Sungai Bahar pada tahun 2016 dengan jumlah 1275 konsumen. Untuk melakukan sebuah penelitian, tidak harus diteliti keseluruhan anggota populasi yang ada. Sampel adalah subset dari populasi atau beberapa anggota dari populasi yang diamati (Ferdinand, 2006).

Dengan meneliti sebagian populasi, diharapkan dapat memperoleh hasil yang dapat menggambarkan sifat populasi yang bersangkutan. maka dari populasi tersebut ditetapkan sampel dengan menggunakan metode Slovin (Husien, 2002;54) dengan rumus sebagai berikut :

$$
\mathrm{n}=\frac{\mathrm{N}}{1+\mathrm{N} \cdot \mathrm{e}^{2}}
$$

$\mathrm{n}=$ Ukuran atau jumlah sampel

$\mathrm{N}=$ Jumlah populasi (debitur)

$\mathrm{e}=$ Presesi yang diharapkan $(0,1$ persen $)$

$$
\begin{aligned}
\mathrm{n} & =\frac{1275}{1+1275(0,1)^{2}} \\
& =99,9 \text { (dibulatkan menjadi } 100 \text { sampel) }
\end{aligned}
$$

Dari perhitungan diatas didapat jumlah sampel yang akan di ambil adalah sebanyak 100 orang responden. Teknik penarikan sampel dilakukan secara non probability simple random sampling. Dimana sampel diambil dengan bertemu secara langsung dengan konsumen yang menggunakan produk honda merek Vario pada PD. Daya Motor Sungai Bahar Muaro Jambi.

\section{Metode Analisis Data}


Dalam penelitian ini untuk mengukur sikap konsumen di gunakan metode deskriftif kualitatif. Jenis data yang digunakan dalam penelitian ini adalah data primer. Menurut Istijanto (2009 ; 44 ) data primer adalah data asli yang dikumpulkan oleh priset untuk menjawab masalah risetnya secara khusus. Data primer dikumpulkan dengan menyebarkan kuisioner yang berbentuk pertanyaan tertutup dimana alternatif jawabannya telah tersedia dari -2 sampai 2 ( menggunakan skala Fishben format lima jawaban ). Dalam penelitian ini digunakan format lima jawaban.

\section{Pengukuran Indikator}

Untuk mendapatkan data mengenai sikap konsumen tersebut. Maka kuesioner yang disebarkan terdiri dari 2 bagian yaitu mengenai evaluasi responden dan kepercayaan responden terhadap atribut yang kemudian dirangkum dalam label.penilaian evaluasi (ei) dan kepercayaan (bi) untuk masing-masing atribut berdasarkan pada skala pisbin dengan ketentuan sebagai berikut :

\begin{tabular}{cc}
\hline Angka & Keterangan \\
\hline-2 & Sangat tidak puas (STP) \\
-1 & Tidak Puas (TP) \\
0 & Cukup Puas (CP) \\
1 & Puas(P) \\
2 & Sangat Puas (SP) \\
\hline
\end{tabular}

Sikap dengan intensitas yang tinggi atau positif ditunjukkan dengan makin mendekatinya skor maksimum yang mungkin dicapai. Sedangkan sikap dengan intensitas yang rendah atau negatif di tunjukkan dengan makin mendekatinya skor maksimum yang mungkin dicapai. Penilaian sikap konsumen berdasarkan kriteria evaluasi dengan interval : kriteria :

Penilaian sikap konsumen berdasarkan rata-rata kepercayaan menggunakan

Untuk mengukur tingkat sikap konsumen terhadap pelayanan, maka digunakan model atribut sikap dari Fishben sebagai berikut :

$A O=\sum B i E i$

$\mathrm{AO}=$ Sikap terhadap objek

$\mathrm{Bi}=$ Kekuatan kepercayaan bahwa objek tersebut memiliki atribut $\mathrm{i}$

$\mathrm{Ei}=$ Evaluasi terhadap atribut $\mathrm{i}$

\section{Kriteria Keputusan}

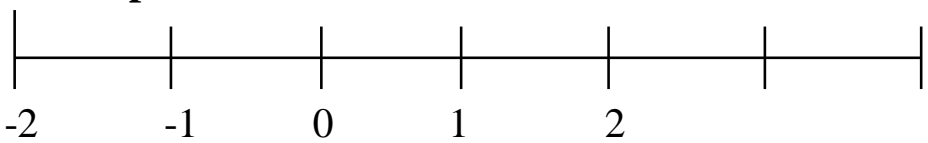

\section{Persamaan Regresi Linear Berganda}

Persamaan regresi linear berganda untuk melihat pengaruh citra merekdan kualitas produk terhadap keputusan konsumen membeli produk sepeda motor Honda merek Vario, digunakan rumus regresi linear berganda menurut Priyanto (2013:131):

Dimana:

$$
Y=a+b_{1} X_{1}+b_{2} X_{2}+b_{3} X_{3}+b_{4} X_{4}+e
$$

$\mathrm{Y}=$ Keputusan pembelian

$\mathrm{b}=$ Koefisien Regresi 


$$
\begin{aligned}
& \mathrm{a}=\text { Konstanta } \\
& \mathrm{X}_{1}=\text { Fungsi Utilitarian } \\
& \mathrm{X}_{2}=\text { Fungsi Ekspresi Nilai } \\
& \mathrm{X}_{3}=\text { Fungsi Mempertahankan Ego } \\
& \mathrm{X}_{4}=\text { Fungsi Pengetahuan } \\
& \mathrm{e}=\text { Standar error }
\end{aligned}
$$

\section{Koefisien Determinasi $\left(\mathbf{R}^{2}\right)$}

Analisis determinasi digunakan untuk mengetahui persentase sumbangan variabel bebas (independen) secara bersama-sama terhadap variabel terikat (dependen).Koefisien determinasi menunjukkan seberapa besar persentase variasi variabel bebas yang digunakan dalam model mampu menjelaskan variasi variabel terikat,Priyanto (2013:143).Koefisen determinasi disimbolkan dengan $r^{2}$ adalah sebuah besaran yang mengukur ketepatan garis regresi.Maksimum nilai $\mathrm{r}^{2}$ dalah $100 \%$ dan minimal 0.Jika $\left(\mathrm{R}^{2}\right)$ yang diperoleh mendekati1 (satu) maka dapat dikatakan semakin kuat model tersebut menerangkanhubungan variabel bebas terhadap variabel terikat. Sebaliknya jika $\left(\mathrm{R}^{2}\right)$ makinmendekati 0 (nol), maka semakin lemah pengaruh variabel-variabel bebasterhadap variabel terikat. Model umum persamaan regresi adalah sebagai berikut :

$$
\begin{aligned}
& \mathrm{R}^{2}=\mathrm{r} \times \mathrm{r} \\
& \text { Dimana : } \\
& \mathrm{R}^{2}=\text { Koefisien determinasi } \\
& \mathrm{r}=\text { Koefesien korelasi }
\end{aligned}
$$

\section{Uji Hipotesis}

Uji t digunakan untuk mengujiapakah variabel bebas citra merek $\left(\mathrm{X}_{1}\right)$, dan Kualitas produk $\left(\mathrm{X}_{2}\right)$ berpengaruh secara parsial terhadap variabel terikat keputusan konsumen membeli (Y), Priyanto (2013:137). Signifikansi pengaruh tersebut dapat diestimasidengan membandingkan antara nilai t hitungdengan nilai t tabel.

Apabila nilai t hitung $>\mathrm{t}$ tabel maka variabel independen secara individual mempengaruhi variabel independen, sebaliknya jika nilai $t$ hitung $<\mathrm{t}$ tabel maka variabel independen secara individual tidak mempengaruhi variabel dependen.

Tingkat signigfikan 5\% $(\alpha=0,05)$.

Kriteria Keputusan :

thitung $>\mathrm{t}$ tabel berarti $\mathrm{H} 0$ ditolak dan menerima $\mathrm{H} 1$

thitung $<\mathrm{t}$ tabel berarti $\mathrm{H} 0$ diterima dan menolak $\mathrm{H} 1$

Uji t juga bisa dilihat pada tingkat signifikansinya:

Jika tingkat signifikansi $<0,05$, maka $\mathrm{H} 0$ ditolak dan $\mathrm{H} 1$ diterima

Jika tingkat signifikansi $>0,05$, maka $\mathrm{H} 0$ diterima dan $\mathrm{H} 1$ ditolak

Uji statistik $\mathrm{f}$

Uji f digunakan untuk menguji apakah variabel bebas citra merek $\left(\mathrm{X}_{1}\right)$, dan kulitas produk $\left(\mathrm{X}_{2}\right)$, berpengaruh secara bersama-sama (simultan) terhadap varibel terikat keputusan konsumen membeli (Y), Priyanto (2013:141). Kriteria pengambilan keputusan:

f hitung > f tabel : berarti H0 di tolak artinya tidak ada pengaruh signifikan citra merek $\left(\mathrm{X}_{1}\right)$, kulitas produk $\left(\mathrm{X}_{2}\right)$ berpengaruh secara simultan terhadap variabel terikat keputusan konsumen membeli (Y). 
Jika f hitung < $\mathrm{f}$ tabel : berarti $\mathrm{H} 1$ diterima ada pengaruh signifikan citra merek $\left(\mathrm{X}_{1}\right)$, kualitas produk $\left(\mathrm{X}_{2}\right)$ berpengaruh secara parsial terhadap variabel terikat keputusan konsumen membeli (Y).

Jika sig > $\alpha(0,05)$, maka $\mathrm{H} 0$ diterima $\mathrm{H} 1$ ditolak.

Jika sig < ́́ $(0,05)$, maka H0 ditolak H1 diterima

Uji korelasi

Menurut Kurniawan (2009:26) korelasi adalah hubungan atau keeratan antara variabel, dimana terdiri 1 variabel independen (bebas) dan 1 variabel dependen (terikat) dan juga mengetahui arah hubungan.adapun pedoman arti korelasi sebagai berikut :

\begin{tabular}{cl}
\hline Interval Koefisien & \multicolumn{1}{c}{ Tingkat hubungan } \\
\hline $0,00-0,199$ & Sangat rendah \\
$0,20-0,399$ & Rendah \\
$0,40-0,599$ & Sedang \\
$0.60-0,799$ & Kuat \\
$0,80-1,000$ & Sangat kuat \\
\hline
\end{tabular}

\section{Hasil penelitian}

Uji statistik $\mathrm{F}$ menunjukkan apakah semua variabel independen yang dimasukkan dalam model mempunyai pengaruh secara bersama-sama terhadap variabel dependen (Ghozali, 2005). Uji ini dilakukkan dengan membandingkan antara nilai $\mathrm{F}$ hitung dengan nilai $\mathrm{F}$ tabel dengan menggunakan tingkat signifikan sebesar 5\%. Jika nilai $\mathrm{F}$ hitung lebih besar dari $\mathrm{F}$ tabel maka secara bersama-sama seluruh variabel independen mempengaruhi variabel dependen. Selain itu, dapat juga dengan melihat nilai probabilitas. Jika nilai probabilitas lebih kecil daripada 0,05 (untuk tingkat signifikansi $=5 \%$ ), maka variabel independen secara bersamasama berpengaruh terhadap variabel dependen. Sedangkan jika nilai probabilitas lebih besar daripada 0,05 maka variabel independen secara serentak tidak berpengaruh terhadap variabel dependen.

\begin{tabular}{|c|c|c|c|c|c|c|}
\hline \multicolumn{7}{|c|}{ ANOVA $^{b}$} \\
\hline \multicolumn{2}{|c|}{ Model } & $\begin{array}{l}\text { Sum of } \\
\text { Squares }\end{array}$ & df & Mean Square & $\mathrm{F}$ & Sig. \\
\hline \multirow[t]{3}{*}{1} & Regression & 286.003 & 4 & 71.501 & 42.193 & $.000^{\mathrm{a}}$ \\
\hline & Residual & 160.987 & 95 & 1.695 & & \\
\hline & Total & 446.990 & 99 & & & \\
\hline
\end{tabular}

a. Predictors: (Constant), Utilitarian, Ekspresi Nilai, Mempertahankan Ego, Pengetahuan

b. Dependent Variable: Keputusan_Pembelian

Uji ANOVA atau Uji F diatas didapat nilai F Hitung sebesar 41,855 dengan probabilitas 0,000. Karena F hitung 42,193 > F Tabel 2,47 dan probabilitas jauh lebih kecil dari 0,05 maka model regresi dapat digunakan untuk memprediksi Keputusan Pembelian (variabel dependen) atau dapat dikatakan bahwa seluruh variabel independen yaitu Fungsi Utilitarian, ekspresi nilai, mempertahankan ego 
dan pengetahuan secara bersama-sama berpengaruh terhadap variabel dependen Keputusan Pembelian konsumen terhadap motor Honda merek Vario.

\section{Analisis Regresi Berganda}

Dari hasil uji regresi berganda maka diperoleh koefisien regresi, nilai $\mathrm{t}$ hitung, dan tingkat signifikansi sebagaimana ditampilkan pada tabel 4.16 dibawah ini :

\section{Coefficients $^{\mathbf{a}}$}

\begin{tabular}{|c|c|c|c|c|c|c|}
\hline \multirow{2}{*}{\multicolumn{2}{|c|}{ Model }} & \multicolumn{2}{|c|}{$\begin{array}{c}\text { Unstandardized } \\
\text { Coefficients }\end{array}$} & \multirow{2}{*}{$\begin{array}{c}\text { Standardized } \\
\text { Coefficients } \\
\text { Beta } \\
\end{array}$} & \multirow[b]{2}{*}{$\mathrm{t}$} & \multirow[b]{2}{*}{ Sig. } \\
\hline & & B & Std. Error & & & \\
\hline \multirow[t]{5}{*}{1} & (Constant) & -2.206 & 1.322 & & -1.668 & .099 \\
\hline & Utilitarian, & .286 & .101 & .215 & 2.844 & .005 \\
\hline & ekspresi nilai, & .374 & .117 & .265 & 3.204 & .002 \\
\hline & $\begin{array}{l}\text { mempertahank } \\
\text { an ego, }\end{array}$ & .234 & .105 & .183 & 2.231 & .028 \\
\hline & pengetahuan & .250 & .064 & .325 & 3.928 & .000 \\
\hline
\end{tabular}

a. Dependent Variable: Keputusan_Pembelian

Dalam penelitian ini digunakan hasil uji regresi yang standardized dikarenakan untuk menyamakan ukuran variabel independen (Fungsi Utilitarian, ekspresi nilai, mempertahankan ego dan pengetahuan, dan Keputusan Pembelian) yang tidak sama. Keuntungan menggunakan hasil regresi yang standardized yaitu mampu mengeliminasi perbedaan unit ukuran pada variabel independen. Selain itu hasil uji regresi yang standardized digunakan karena ingin melihat tingkat prioritas.

Berdasarkan pada hasil analisis yang telah dilakukan tersebut, maka persamaan regresi yang terbentuk adalah sebagai berikut :

$$
Y=-2.206+0,286 X_{1}+0,374 X_{2}+0,234 X_{3}+0,250 X_{4}
$$

Dari persamaan regresi diatas dapat diketahui bahwa koefisien dari persamaan regresinya adalah positif. Hal ini dapat dijelaskan sebagai berikut :

1. Variabel independen Fungsi Utilitarian $\left(\mathrm{X}_{1}\right)$ berpengaruh positif terhadap Keputusan Pembelian (Y) dengan nilai koefisien sebesar 0,286. Artinya, semakin tinggi pengaruh Fungsi Utilitarian terhadap pembelian produk sepeda motor Honda Merek Vario $\left(\mathrm{X}_{1}\right)$, maka semakin tinggi keputusan pembelian (Y).

2. Variabel independen Fungsi Ekspresi Nilai $\left(\mathrm{X}_{2}\right)$ berpengaruh positif terhadap Keputusan Pembelian (Y) dengan nilai koefisien sebesar 0,374. Artinya, semakin tinggi pengaruh Fungsi Ekspresi Nilai terhadap pembelian produk sepeda motor Honda Merek Vario $\left(\mathrm{X}_{2}\right)$, maka semakin tinggi keputusan pembelian (Y).

3. Variabel independen Fungsi Mempertahankan Ego $\left(\mathrm{X}_{3}\right)$ berpengaruh positif terhadap Keputusan Pembelian (Y) dengan nilai koefisien sebesar 0,234. Artinya, semakin tinggi pengaruh Fungsi Mempertahankan Ego terhadap pembelian produk sepeda motor Honda Merek Vario $\left(\mathrm{X}_{3}\right)$, maka semakin tinggi keputusan pembelian konsumen (Y). 
4. Variabel independen fungsi Pengetahuan $\left(\mathrm{X}_{4}\right)$ berpengaruh positif terhadap Keputusan Pembelian (Y) dengan nilai koefisien sebesar 0,250. Artinya, semakin tinggi pengaruh fungsi Pengetahuan terhadap pembelian produk sepeda motor Honda Merek Vario $\left(\mathrm{X}_{4}\right)$, maka semakin tinggi keputusan pembelian (Y).

Berikut ini dapat dilihat kesimpulan dari pengolahan regresi berganda dalam melihat pengaruh Fungsi Utilitarian $\left(\mathrm{X}_{1}\right)$, Fungsi Ekspresi Nilai $\left(\mathrm{X}_{2}\right)$, Fungsi Mempertahankan Ego $\left(\mathrm{X}_{3}\right)$, Fungsi Pengetahuan $\left(\mathrm{X}_{4}\right)$ terhadap Keputusan Pembelian (Y) .

1. Nilai t hitung pada variabel Utilitarian $\left(\mathrm{X}_{1}\right)$ adalah 2,844 dengan tingkat signifikansi 0,005. Karena nilai t hitung 2,844 > nilai t tabel 1,661 dan tingkat signifikansi $0,005<$ probabilitas signifikansi $\alpha=0,05$, maka Ho ditolak dan Ha diterima. Hal ini berarti variabel Utilitarian secara individual berpengaruh positif dan signifikan terhadap Keputusan Pembelian.

2. Nilai t hitung pada variabel Ekspresi Nilai $\left(\mathrm{X}_{2}\right)$ adalah 3,204 dengan tingkat signifikansi 0,002. Karena nilai t hitung 3,204> nilai t tabel 1,661 dan tingkat signifikansi $0,002<$ probabilitas signifikansi $\alpha=0,05$, maka Ho ditolak dan Ha diterima. Hal ini berarti variabel Ekspresi Nilai secara individual berpengaruh positif dan signifikan terhadap Keputusan Pembelian.

3. Nilai $t$ hitung pada variabel Mempertahankan Ego $\left(\mathrm{X}_{3}\right)$ adalah 2,231 dengan tingkat signifikansi 0,028. Karena nilai t hitung 2,231 > nilai t tabel 1,661 dan tingkat signifikansi $0,028<$ probabilitas signifikansi $\alpha=0,05$, maka Ho ditolak dan Ha diterima. Hal ini berarti variabel Mempertahankan Ego secara individual berpengaruh positif dan signifikan terhadap Keputusan Pembelian.

4. Nilai t hitung pada variabel Pengetahuan $\left(\mathrm{X}_{4}\right)$ adalah 3,928 dengan tingkat signifikansi 0,000. Karena nilai t hitung 3,928 > nilai t tabel 1,661 dan tingkat signifikansi $0,000<$ probabilitas signifikansi $\alpha=0,05$, maka Ho ditolak dan Ha diterima. Hal ini berarti variabel Pengetahuan secara individual berpengaruh positif dan signifikan terhadap Keputusan Pembelian.

\begin{tabular}{rlcc}
\hline No. & \multicolumn{1}{c}{ Variabel } & $\begin{array}{c}\text { Nilai } \\
\text { Koefisien }\end{array}$ & Pengaruh \\
\hline 1 & Fungsi Utilitarian $\left(\mathrm{X}_{1}\right)$ & 0,286 & Positif \\
2 & Fungsi Ekspresi Nilai $\left(\mathrm{X}_{2}\right)$ & 0,374 & Positif \\
3 & Fungsi Mempertahankan Ego $\left(\mathrm{X}_{3}\right)$ & 0,234 & Positif \\
4 & Fungsi Pengetahuan $\left(\mathrm{X}_{4}\right)$ & 0,250 & Positif \\
\hline
\end{tabular}

Uji validitas digunakan untuk mengukur sah atau valid tidaknya suatu kuesioner. Suatu kuesioner dinyatakan valid jika pertanyaan pada kuesioner mampu mengungkapkan sesuatu yang akan diukur oleh kuesioner tersebut. Uji validitas dilakukan dengan membandingkan antara nilai $r$ hitung dengan $r$ tabel untuk degree of freedom $(\mathrm{df})=\mathrm{n}-2$, dalam hal ini $\mathrm{n}$ adalah jumlah sampel dalam penelitian ini, yaitu $(n)=100$. Maka besarnya df dapat dihitung 100-2 = 98. Dengan $\mathrm{df}=98$ dan alpha $=0,05$ didapat $\mathrm{r}$ tabel $=0,1966$ (dengan melihat $\mathrm{r}$ tabel pada $\mathrm{df}=98$ dengan uji dua sisi). Jika nilai $r$ hitung lebih besar daripada $r$ tabel dan bernilai positif, maka butir pertanyaan atau indikator tersebut dinyatakan valid (Ghozali, 2005).

Dari tabel $\mathrm{r}$ dengan $\mathrm{df}=\mathrm{n}-2$ (98) pada tingkat signifikansi $5 \%$ diperoleh angka sebesar 0,1966. Sedangkan rhitung dari perhitungan semuanya melebihi 
rtabel sehingga dapat disimpulkan bahwa butir-butir pertanyaan pada variabel bukti budaya dapat dinyatakan valid. Berikut hasil perhitungan yang dilakukan dengan bantuan SPSS 16.0 pada tabel 4.18 sebagai berikut :

Uji Validitas Variabel

\begin{tabular}{ccccc}
\hline Variabel & $\begin{array}{c}\text { Item } \\
\text { /Pertanyaan }\end{array}$ & r Hitung & r Tabel & Keterangan \\
\hline Fungsi & $\mathrm{X}_{1} 1$ & 0,396 & 0,1966 & Valid \\
Utilitarian $\left(\mathrm{X}_{1}\right)$ & $\mathrm{X}_{1} 2$ & 0,431 & 0,1966 & Valid \\
& $\mathrm{X}_{1} 3$ & 0,427 & 0,1966 & Valid \\
Fungsi Ekspresi & $\mathrm{X}_{2} 1$ & 0,550 & 0,1966 & Valid \\
Nilai $\left(\mathrm{X}_{2}\right)$ & $\mathrm{X}_{2} 2$ & 0,510 & 0,1966 & Valid \\
Fungsi & $\mathrm{X}_{2} 3$ & 0,405 & 0,1966 & Valid \\
Mempertahankan & $\mathrm{X}_{3} 1$ & 0,425 & 0,1966 & Valid \\
Ego & $\mathrm{X}_{3} 2$ & 0,414 & 0,1966 & Valid \\
(X) & $\mathrm{X}_{3} 3$ & 0,460 & 0,1966 & Valid \\
Fungsi & $\mathrm{X}_{4} 1$ & 0,738 & 0,1966 & Valid \\
Pengetahuan & $\mathrm{X}_{4} 2$ & 0,734 & 0,1966 & Valid \\
(X) & $\mathrm{X}_{4} 3$ & 0,654 & 0,1966 & Valid \\
Keputusan & $\mathrm{Y} 1$ & 0,709 & 0,1966 & Valid \\
Pembelian $(\mathrm{Y})$ & $\mathrm{Y} 2$ & 0,638 & 0,1966 & Valid \\
\hline
\end{tabular}

Berdasarkan tabel diatas dapat diketahui bahwa pertanyaan-pertanyaan pada variabel independen (Fungsi Utilitarian, Ekspresi Nilai, Mempertahankan Ego dan Pengetahuan) dan variabel dependen (Keputusan Pembelian ) memiliki $r$ hitung (Corrected Item - Total Correlation) $>$ daripada $r$ tabel, maka dapat disimpulkan bahwa keseluruhan item pertanyaan (indikator) yang terdapat dalam seluruh variabel tersebut adalah valid.

\section{Uji Reliabilitas}

Pengukuran reliabilitas dilakukan dengan cara One Shot atau pengukuran sekali saja. Disini pengukurannya hanya sekali dan kemudian hasilnya dibandingkan dengan pertanyaan lain atau mengukur korelasi antar jawaban pertanyaan. SPSS memberikan fasilitas untuk mengukur reliabilitas dengan uji statistik Cronbach Alpha $(\alpha)$. Suatu variabel dikatakan reliabel jika memberikan nilai Cronbach Alpha > 0,60.

\section{Hasil Uji Reliabilitas Variabel}

\begin{tabular}{lccccc}
\hline \multicolumn{1}{c}{ Variabel } & \multicolumn{2}{c}{$\begin{array}{c}\text { Nilai } \\
\text { Cronbach } \\
\text { Alpha }\end{array}$} & Keterangan & $\mathbf{0 , 6 0}$ & Kesimpulan \\
\hline Utilitarian & $\left(\mathrm{X}_{1}\right)$ & 0,607 & $>$ & 0,60 & Reliabel \\
Ekspresi Nilai & $\left(\mathrm{X}_{2}\right)$ & 0,670 & $>$ & 0,60 & Reliabel \\
Mempertahankan Ego & $\left(\mathrm{X}_{3}\right)$ & 0,620 & $>$ & 0,60 & Reliabel \\
Pengetahuan & $\left(\mathrm{X}_{4}\right)$ & 0,834 & $>$ & 0,60 & Reliabel \\
Keputusan Pembelian & $(\mathrm{Y})$ & 0,795 & $>$ & 0,60 & Reliabel \\
\hline
\end{tabular}


Hasil pengujian menunjukkan nilai Cronbach Alpha dari keseluruhan variabel adalah lebih besar dari 0,60 sehingga dapat disimpulkan bahwa variabel yang digunakan adalah reliabel.

\section{Uji Normalitas}

Uji normalitas bertujuan untuk menguji apakah dalam model regresi, variabel pengganggu atau residual memiliki distribusi normal atau tidak (Ghozali, 2005). Dalam penelitian ini menggunakan Normal P-P Plots yaitu cara untuk mendeteksi apakah residual berdistribusi normal atau tidak.

\section{Uji Koefisien Determinasi $\left(\mathbf{R}^{2}\right)$}

Uji koefisien determinasi $\left(\mathrm{R}^{2}\right)$ digunakan untuk mengukur seberapa jauh kemampuan model dalam menerangkan variasi variabel dependen (Ghozali, 2005). Nilai $R^{2}$ yang semakin mendekati 1 , berarti variabel-variabel independen memberikan hampir semua informasi yang dibutuhkan untuk memprediksi variasi variabel independen. Koefisien determinasi yang digunakan adalah nilai Adjusted $\mathrm{R}$ Square karena lebih dapat dipercaya dalam mengevaluasi model regresi. Nilai Adjusted R Square dapat naik atau turun apabila satu variabel independen ditambahkan kedalam model. Berbeda dengan nilai $\mathrm{R}^{2}$ yang pasti akan meningkat setiap tambahan satu variabel independen, tidak perduli apakah variabel tersebut berpengaruh secara signifikan terhadap variabel dependen.

Berikut tabel untuk melihat koefisien determinasi dalam mengukur seberapa jauh kemampuan model dalam menerangkan variasi variabel dependen dibawah ini :

\section{Model Summary}

\begin{tabular}{lrrrr}
\hline Model & R & R Square & $\begin{array}{c}\text { Adjusted R } \\
\text { Square }\end{array}$ & $\begin{array}{l}\text { Std. Error of } \\
\text { the Estimate }\end{array}$ \\
\hline 1 & $.800^{\mathrm{a}}$ & .640 & .625 & 1.30177 \\
\hline
\end{tabular}

a. Predictors: (Constant), Utilitarian, Ekspresi Nilai, Mempertahankan Ego, Pengetahuan

Dari tabel koefisien determinasi $\left(\mathrm{R}^{2}\right)$ diatas menunjukkan besarnya adjusted $\mathrm{R}^{2}$ adalah 0,640, hal ini berarti 64\% variasi Keputusan Pembelian dapat dijelaskan oleh variasi dari ke 4 variabel independen.

\section{Intepretasi Hasil Penelitian}

Pada bagian ini akan dipaparkan pembahasan mengenai hasil analisis yang telah dilakukan. Hasil analisis tersebut dijelaskan sebagai berikut:

1. Pernyataan yang menyatakan bahwa "semakin tinggi pengaruh Utilitarian terhadap Pembelian Produk Sepeda Motor Honda Merek Vario $\left(\mathrm{X}_{1}\right)$, maka semakin tinggi keputusan pembelian (Y)" dapat diterima, karena variabel Utilitarian berpengaruh positif dan signifikan terhadap Keputusan Pembelian dengan nilai koefiseien regresi sebesar 0,215. Hal tersebut dibuktikan dengan hasil analisis uji t yang menunjukkan nilai t hitung 2,844 > nilai t tabel 1,661 dan tingkat signifikansi $0,005<$ probabilitas signifikansi $\alpha=0,05$.

2. Pernyataan yang menyatakan bahwa "semakin tinggi pengaruh Ekspresi Nilai terhadap Pembelian Produk Sepeda Motor Honda Merek Vario $\left(\mathrm{X}_{2}\right)$, maka semakin tinggi keputusan pembelian (Y)" dapat diterima, karena variabel Ekspresi Nilai berpengaruh positif dan signifikan terhadap Keputusan Pembelian dengan nilai koefiseien regresi sebesar 0,265. Hal tersebut 
dibuktikan dengan hasil analisis uji t yang menunjukkan nilai t hitung 3,204 > nilai t tabel 1,661 dan tingkat signifikansi $0,002<$ probabilitas signifikansi $\alpha=$ 0,05 .

3. Pernyataan yang menyatakan bahwa "semakin tinggi pengaruh Mempertahankan Ego terhadap Pembelian Produk Sepeda Motor Honda Merek Vario $\left(\mathrm{X}_{3}\right)$, maka semakin tinggi keputusan pembelian $(\mathrm{Y})$ " dapat diterima, karena variabel Mempertahankan Ego berpengaruh positif dan signifikan terhadap Keputusan Pembelian dengan nilai koefiseien regresi sebesar 0,183. Hal tersebut dibuktikan dengan hasil analisis uji $\mathrm{t}$ yang menunjukkan nilai $\mathrm{t}$ hitung 2,231 > nilai t tabel 1,661 dan tingkat signifikansi $0,028<$ probabilitas signifikansi $\alpha=0,05$.

4. Pernyataan yang menyatakan bahwa "semakin tinggi pengaruh Pengetahuan terhadap Pembelian Produk Sepeda Motor Merek Vario $\left(\mathrm{X}_{4}\right)$, maka semakin tinggi keputusan pembelian (Y)" dapat diterima, karena variabel Pengetahuan berpengaruh positif dan signifikan terhadap Keputusan Pembelian dengan nilai koefiseien regresi sebesar 0,325. Hal tersebut dibuktikan dengan hasil analisis uji $\mathrm{t}$ yang menunjukkan $\mathrm{t}$ hitung 3,928 > nilai t tabel 1,661 dan tingkat signifikansi $0,000<$ probabilitas signifikansi $\alpha=0,05$.

\section{SIMPULAN}

Berdasarkan uraian pada bab-bab sebelumnya, maka penulis dapat menarik kesimpulan sebagai berikut :

1. Dari hasil skala Fishben, sikap konsumen terhadap sepeda motor Honda vario berdasarkan klasifikasi empat sikap tersebut Fungsi Utilitarium skor tertinggi 151 konsumen merasa puas dengan penawatan cicilan, Fungsi Ekspresi Nilai skor tertinggi 125 konsumen merasa puas variasi produk, Fungsi Mempertahankan Ego skor tertinggi 112 konsumen merasa puas dengan ketersediaan suku cadang, Fungsi Pengetahuan skor tertinggi 114 konsumen merasa puas dengan promosi iklan sepeda motor Honda merek Vario.

2. Uji F didapat nilai $F$ Hitung sebesar 41,855 dengan probabilitas 0,000. Karena F hitung 42,193 > F Tabel 2,47 dan probabilitas jauh lebih kecil dari 0,05 maka model regresi dapat digunakan untuk memprediksi Keputusan Pembelian (variabel dependen) atau dapat dikatakan bahwa seluruh variabel independen yaitu Fungsi Utilitarian, ekspresi nilai, mempertahankan ego dan pengetahuan secara bersama-sama berpengaruh terhadap variabel dependen Keputusan Pembelian konsumen terhadap motor Honda merek Vario.

3. Koefisien determinasi $\left(\mathrm{R}^{2}\right)$ diatas menunjukkan besarnya adjusted $\mathrm{R}^{2}$ adalah 0,640, hal ini berarti 64\% variasi Keputusan Pembelian dapat dijelaskan oleh variasi dari ke 4 variabel independen.

4. Hasil analisis uji $t$ diatas adalah nilai t hitung pada variabel Utilitarian $\left(X_{1}\right)$. variabel Ekspresi Nilai $\left(\mathrm{X}_{2}\right)$ Mempertahankan Ego $\left(\mathrm{X}_{3}\right)$, variabel Pengetahuan $\left(\mathrm{X}_{4}\right)$ tingkat signifikansi $0,000<$ probabilitas signifikansi $\alpha=0,05$, maka Ho ditolak dan Ha diterima. Hal ini berarti variabel $\mathrm{X} 1, \mathrm{X} 2, \mathrm{X} 3, \mathrm{X} 4$ berpengaruh positif dan signifikan terhadap Keputusan Pembelian. 


\section{DAFTAR PUSTAKA}

Bilson,S. 2004. Panduan Riset Perilaku Konsumen. Gramedia Pustaka Utama, Jakarta

Danang, S. 2012. Konsep Dasar Riset Pemasaran dan Perilaku Konsumen .CAPS ( Center for Academic Publishing Service). Yogyakarta.

Durianto, D. DKK, 2001. Strategi Menaklukan Pasar melalui Riset Ekuitas dan Perilaku Merek. Gramedia Pustaka Utama. Jakarta.

Engel, J.DKK, 2001. Perilaku Konsumen, Alih Bahasa drs. Budijanto. Edisi Keenam Jilid 2, Bina Rupa Aksara. Jakarta.

Fandy, T. 2008. Strategi Pemasaran Edisi 1. Andi Offset. Yogyakarta.

Kotler, P, 2002. Manajemen Pemasaran Edisi Milenium, Jilid 1 . Prenhallindo.Jakarta.

Kotler, P, 2002. Manajemen Pemasaran Edisi Milenium, Jilid 2 . Prenhallindo.Jakarta.

Nugroho, S. 2003. Perilaku Konsumen.Kencana. Jakarta.

Sadono, S. 2009. Teori Pengantar Ekonomi, Edisi Ketiga PT. Raja grafindo Persada. Jakarta.

Stanton, W 1989. Prinsip Pemasaran, Alih Bahasa Drs. Yohanes L. Edisi Ketujuh Jilid 1. Erlangga, Jakarta

Sugiarto, DKK. 2003. Teknik Sampling. Gramedia Pustaka Utama. Jakarta

Sutisna, 2003.Prilaku Konsumen dan Komunikasi Pemasran Remaja, Rosda Karya, Bandung. 